\section{Building a}

Multi-Format

\section{Graduate Student Information}

Literacy Program

\section{Kathy Christie Anders}

\begin{abstract}
Kathy Christie Anders is Associate Professor and Graduate Studies Librarian at Texas A\&M University, College Station, Texas.
\end{abstract}

Correspondence concerning this column should be addressed to Sarah LeMire; e-mail:slemire@umich.edu.
College and university library instruction programs often focus on providing information literacy instruction for undergraduate students. In this article, Kathy Christie Anders shares how she has developed an information literacy program specifically aimed at graduate students. She discusses the challenges of embedding information literacy into graduate and professional school curricula, particularly across degree programs. She also discusses the advantages of taking a multi-pronged approach to instruction for graduate students, especially in an instructional context that makes programmatic implementation a challenge.-Editor

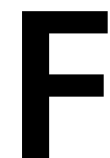

or many years, undergraduate success has been a central part of many conversations concerning academic libraries, and indeed about universities more broadly. Recently, though, there has been growing public interest in the fates of graduate students. From national discussions about job markets for PhD students, graduate student mental health, and graduate student debt, ${ }^{1}$ the conversation has moved into the realm of academic librarianship. Academic librarians have long helped graduate students, just as they have undergraduates and faculty members, but in the last twenty years or so graduate students have begun to be viewed as a specific population with unique needs. We see this in the development of professional groups and events focused on graduate students; the biannual Transforming Libraries for Graduate Students Conference started in 2016 and will be meeting for the third time in March 2020. ${ }^{2}$ In 2017 the Academic Library Services for Graduate Students Interest Group in ACRL was formed. ${ }^{3}$ In 2009, the United States Electronic Thesis and Dissertation Association Conference was founded, sponsored by both graduate offices and academic libraries. ${ }^{4}$

One particular area of interest is in information literacy education for graduate students, a population that consists of masters, doctoral, and professional students. Graduate information literacy needs to be considered in its own right, not only because of the differences between graduate and undergraduate needs, but because of the spectrum of needs between entering masters and advanced doctoral students. ${ }^{5}$ Therefore it is helpful to consider advanced information literacy skills and knowledge as increasing with further education and practice. Information literacy, like any other discipline, scales up in terms of specialization and complexity. Graduate students, moving from recent undergraduates to academic or industry professionals, encounter increasingly nuanced and complex information literacy concepts and levels as they move through their education. For example, at the graduate 
level, students must not only understand the information life-cycle, but where their own research and publication live within that life cycle. Information literacy for graduate students is not just about advanced research, but about scholarly production and publication within a given discipline.

While certain graduate populations, such as those in information science, may view themselves as having advanced information literacy skills, ${ }^{6}$ there is evidence to suggest that some graduate students may not be fully proficient. ${ }^{7}$ And while it is helpful to consider whether or not graduate students have achieved the proficiency levels necessary for the type of work they are doing, it is also worth investigating what advanced information literacy looks like. The Framework for Information Literacy for Higher Education is helpful in that it establishes "dispositions" rather than competency levels, and these dispositions are applicable to all stages of education. ${ }^{8}$ Nina Exner successfully shows how the frame "Research as Inquiry" can be used to approach teaching those engaged in original research, such as doctoral students. ${ }^{9}$ Given the general integration of creation and context into the Framework, there is room to envision how it applies to the seasoned academic professional and the freshman alike.

\section{THE PROGRAM}

Texas A\&M University is a large public research university. As of the 2019-2020 academic year, it had nearly 15,000 graduate and professional students, and more than 69,000 students enrolled overall. ${ }^{10}$ In terms of administrative organization, the Office of Graduate and Professional Students is responsible for graduate student records, dissertation and thesis review, and professional development. In College Station, there are fourteen individual colleges that enroll graduate and professional students, with an additional two such colleges at other locations in the state. Many of the graduate programs are residential in nature, but as of 2020 there are forty-eight distance degrees offered, most of them at the masters level. ${ }^{11}$

In terms of creating information literacy programming for the graduate student population, the University Libraries have implemented a multi-format approach. In addition to liaison librarians who are invited into classrooms, graduate students can choose to participate in our workshops, retreats, and short courses. This structure of programming within the University Libraries is relatively new. The position of Graduate Studies Librarian was created in 2014 in the Learning and Outreach unit, although many librarians in the University Libraries had been working with graduate students for far longer. With the creation of that position came the development of the current program.

Prior to 2014, librarians had been offering course-integrated classes and some stand-alone workshops, depending upon requests and relationships with departments. Subsequent to 2014, the Libraries maintained their previous instruction while piloting retreats, offered in partnership with the University Writing Center, and short courses. Additionally, the Libraries integrated their graduate workshops into the University professional development program for graduate and professional students. One of the benefits of the structure of the program has been that librarians can experiment with new forms of instruction and offer a diverse set of learning formats. This allows our librarians maximum flexibility in developing learning opportunities, and benefits graduate students by giving them choices about how they prefer to participate in instruction.

\section{Workshops}

One of the long-term staples of our graduate information literacy program has been workshops. They are generally about an hour long and are taught by librarians and library employees from public services and scholarly communications in their areas of expertise. While not always strictly the case, liaison librarians tend to teach workshops on topics related to their disciplines, and learning and outreach and scholarly communication librarians teach workshops that are broadly applicable to the entire graduate and professional student community. Workshops are popular with graduate students, and library literature shows that they can be effective formats for teaching information literacy. ${ }^{12}$

Graduate workshops require a high level of expertise to teach, so the topics offered depend upon which librarians are available to teach them. In addition to offering workshops that cover how to use disciplinary databases, topics offered in the past five years include:

- Citation management software

- Copyright for both research and teaching

- Data management

- Scholarly identity

- Keeping up with scholarly literature

- International research

These workshops generally intersect with one frame of the Framework for Information Literacy for Higher Education, often reflecting one or two knowledge practices. They are clearly focused on information literacy, albeit at a more specialized level. Many of the workshops blend information literacy with scholarly communications, which reflects literature suggesting that for graduate students, becoming adept at information problem solving means learning skills encompassing both scholarly communications and information literacy. ${ }^{13}$

While workshops are generally well-attended, with ten to twenty-five attendees on average, the Libraries participate in a graduate student professional development program to incentivize student attendance. This program is run by our Office of Graduate and Professional Students, and students who attend professional development events earn units that count toward three progressively-tiered certificates. These 
certificates do not appear on students' transcripts, but they are able to list them on CVs. The Libraries' participation in this program contributes to the Office of Graduate and Professional Students' goal of increasing professional development opportunities for students and gives students a way to indicate the workshops they participate in apart from their degree coursework. This collaboration between university units also provides opportunities for the Libraries to develop additional collaborative relationships with other units that participate, such as the Center for Teaching Excellence.

\section{Short Courses}

Workshops, while being easy to offer, are limited in the depth of instruction that is suited to them. There is only so much one can cover in a one to two hour session. To allow librarians to delve into more depth, the Libraries piloted a set of three "short courses," all related to topics concerning data. In these short courses, students signed up to attend classes once or twice a week for four to five weeks. Each session lasted between one and two hours. The intent was to more closely replicate the traditional teaching structure of the university, with students being in cohorts and meeting with the same instructor over a regular period of time. There was enormous demand for the courses, with two courses each having waitlists of more than 150 people. Another was able to accommodate $100+$ students and still had a waitlist. This was perhaps due to the popularity of the topics (GIS, data literacy, and data management), but also because the nature of the short courses allowed enough time for students to noticeably improve skill levels in those areas.

While students were enthusiastic about the topics and initial attendance was very high, instructors found that attendance rates dwindled as the courses ran on, such that the final completion numbers were considerably lower than registrations. For example, the GIS short course had a 50 percent completion rate. ${ }^{14}$ Students in the course indicated that they were interested, but that it was difficult to complete all of the sessions while managing the rest of their academic workload. Instructors, too, found the short courses very work-intensive. It is worth noting that since the Libraries are not a credit-bearing college, there was no way to offer these short courses for credit or have them appear on transcripts. It would seem reasonable to say that if completion of the short course were reflected on academic transcripts, completion rates would rise.

There is evidence that the cohort-based short course model of information literacy education for graduate students can be very effective. ${ }^{15}$ It certainly allows instructors to create learning opportunities that go into far more depth than a typical one-shot workshop, which is beneficial to students because the skills they are developing are complex. We are interested in revisiting this model in the future when we can find a way to better incentivize completion, perhaps by integrating these into the university graduate professional development program.

\section{Retreats}

In addition to workshops and short courses, the Libraries host research retreats with the University Writing Center. These retreats are targeted at graduate students who are in the process of writing their thesis or dissertation proposals. They last from one to two days and offer students a chance to research and write together for most of the day. The days begin and end with short presentations about writing and research techniques. Embedded into these retreats are thirtyminute appointments with subject librarians and writing consultants. During an appointment with a librarian, a student might learn more about ways to search for information, how to manage citations, or how copyright applies to their work. We hold these retreats twice a year, with thirty to thirty-five attendees each time. They are incredibly popular, with registrations filling up within an hour of going live.

The aim of these retreats is twofold; first, it provides students the chance to work in a communal program focused on facilitating academic research and writing. Students benefit from being with their peers, and during the retreats, catering is brought in throughout the day so that students can maintain their energy and focus on their work. The second is for students to work with consultants and librarians on stumbling blocks in their research. Their interactions with librarians are generally educational in nature and involve information literacy learning on the part of the students. Students might learn about fair use practices, new information resources, or how to look up recent dissertations that have come out of their departments. In many cases these appointments with librarians during the retreat result in follow-up consultations.

\section{Course-Integrated Sessions}

One of the longer-standing ways of incorporating information literacy into graduate studies is through classroom invitations. Much as with undergraduate classes, professors teaching graduate classes request that their subject librarians teach a session for their class either at the library or in their classrooms. At our library, those instruction collaborations are managed and offered by individual liaison librarians, and occur with different levels of embeddedness and integration. In some instances, librarians are teaching conventional oneshots. In other cases they are more integrated into assignments or longer workshops and projects. Library class sessions are the most common form of information literacy instruction at the Texas A\&M University Libraries. In the 2019 calendar year, the Libraries taught just over one hundred courseintegrated library sessions for graduate and professional students. ${ }^{16}$ While there is evidence that graduate students prefer in-person workshops to class instruction sessions, ${ }^{17}$ these are still important to teach because they are requested by faculty and can be tailored to specific courses and assignments. Such classes represent some of the Libraries' best opportunities to be embedded in departments and courses. 


\section{IMPLEMENTATION CONSIDERATIONS}

\section{Lack of Common Insertion Points}

Undergraduate information literacy programs have had great success by targeting high-volume lower-level classes for information literacy integration. Introductory composition, first-year experience, and other general education requirements are natural areas where information literacy can be introduced to the curriculum and reach large numbers of students. Education programs can also be implemented relatively easily across departments and disciplines, since general education and introductory classes can be taken by students across a variety of majors. These classes, such as introductory composition, are often administered by one department, like English, making collaborations easier to achieve.

Graduate programs, by and large, do not have a similar type of first-year experience course or pervasive single introductory course. This makes relying on only one type of course-integration difficult. If a first-year or commoncourse movement for graduate students begins in the future, that would be a natural place to look to embed information literacy. At the moment, however, offering many different types of programming allows academic programs, individual faculty, and graduate students multiple opportunities to increase information literacy skills.

Apart from having a multi-format information literacy program, in the future we may try to integrate information literacy into an entire academic program. Maria Grant and Marlowe Berg's 2003 study indicates that San Diego State University/University of San Diego successfully integrated information literacy learning into all of the core courses for their Joint Doctoral Program in education. ${ }^{18}$ While finding a point at which an information literacy program might be ideal, in the meantime targeting individual programs may be another way to systematically integrate information literacy into graduate and professional curricula.

\section{Time after Coursework}

While masters and professional students generally are in coursework for most of the time during their degree programs, doctoral students usually spend a considerable amount of time, often years, doing independent research. At this point their main supervision is through their advisor, and after ending coursework they may feel somewhat isolated. ${ }^{19}$ To reach students at this phase, it is important to make sure that faculty advisors, departmental graduate directors, and graduate college/office members are aware of the information literacy learning opportunities that are available.

At the Texas A\&M University Libraries, we have developed relationships with many of the other administrative and academic support units on campus, such as the Office of Graduate and Professional Students, the University Writing
Center, the Center for Teaching Excellence, and International Students Services. Through relationships and collaborations with these offices, we are able to extend our outreach to administrators, advisors, and faculty members who continue to work with graduate students after they have completed their coursework. We also organize learning opportunities, such as retreats and workshops, that are targeted to students completing milestone projects after coursework, such as submitting proposals and dissertations.

\section{Next Steps and Conclusion}

There is not one single method of information literacy teaching that we rely on alone in the Libraries. Each has its own opportunities and weaknesses, so relying on one method alone, such as workshops, is not sufficient to reach all graduate students. By maintaining a program that consists of multiple formats, the Libraries have the ability to experiment with different models of education while reaching more students than we could with one format alone. This has afforded us the ability to experiment and innovate while drawing on the strengths of many of our librarians.

The program does not exist on its own; it requires work to inform graduate students and faculty members about the learning opportunities that are available. The program dovetails with our outreach programming to graduate students, which includes orientation sessions, resource fairs, and stress-busting events. Library literature suggests that promotion is an important part of maintaining a successful graduate information literacy program ${ }^{20}$ and we have found that in order to keep up attendance, we have to let students know what we have to offer. In the future, it would be ideal to integrate information literacy more into the graduate curriculum, so that graduate students could be ensured of information literacy learning, rather than taking workshops only if they happen to attend an outreach event or see our marketing materials. It is fairly common for students to say after workshops that they wished they had known about the topic earlier in their graduate careers, but early in their careers they may not know about all of services the Libraries provide, especially given the size of our university and the many offices on campus that target graduate students. We have found that the information literacy program is in demand, since workshops and retreats regularly lead to more consultations with students, indicating the need for additional learning opportunities where students can learn more deeply about the research and scholarly dissemination processes.

As our graduate information literacy program progresses, we will continue to experiment with types of offerings while maintaining our current core. The intersection of scholarly communications and information literacy has been one of increasing interest to our students, and this is an area that will continue to grow in the future, particularly as the Libraries have recently created a new data management unit. Future steps also include expanding our online offerings to 
make sure that our distance education students have the same opportunities as our residential students do. Academic library services focused on graduate students only continue to grow, both locally and nationally, so we anticipate this being an area of need for a long time to come.

\section{References}

1. Teresa M. Evans et al., "Evidence for a Mental Health Crisis in Graduate Education," Nature Biotechnology 36 (2018): 282-84, https://doi.org/10.1038/nbt.4089; Laura McKenna, "The EverTightening Job Market for Ph.D.s," The Atlantic, April 21, 2016, https://www.theatlantic.com/education/archive/2016/04 /bad-job-market-phds/479205/; Jaymes Pyne and Eric Grodsky, "Inequality and Opportunity in a Perfect Storm of Graduate Student Debt," Sociology of Education 93, no. 1 (January 2020): 20-39, https://doi.org/10.1177/0038040719876245.

2. "Transforming Libraries for Graduate Students," Transforming Libraries for Graduate Students, accessed January 28, 2020, https://digitalcommons.kennesaw.edu/gradlibconf/.

3. "Academic Library Services for Graduate Students Interest Group," Association of College and Research Libraries, accessed January 28, 2020, http://www.ala.org/acrl/aboutacrl/directoryof leadership/interestgroups/acr-igalsgs.

4. "About the USETDA," United States Electronic Thesis and Dissertation Association, accessed January 28, 2020, https://www .usetda.org/usetda-home/.

5. Amy Catalano, "Patterns of Graduate Students' Information Seeking Behavior: A Meta-Synthesis of the Literature," Journal of Documentation 69, no. 2 (2013): 269, https://doi .org/10.1108/00220411311300066; Bonnie L. Fong et al., "Assessing and Serving the Workshop Needs of Graduate Students," Journal of Academic Librarianship 42, no. 5 (2016): 574, https://doi.org/10.1016/j.acalib.2016.06.003.

6. María Pinto et al., "Information Competence of Doctoral Students in Information Science in Spain and Latin-America: A Self-Assessment," Journal of Academic Librarianship 38, no. 2 (2013): 144-54, https://doi.org/10.1016/j.acalib.2012.08.006

7. Valerie Perrett, "Graduate Information Literacy Skills: The 2003 ANU Skills Audit," Australian Library Journal 53, no. 2 (2004): 161-71, https://doi.org/10.1080/00049670.2004.107216 22; Kate Conway, "How Prepared Are Students for Postgraduate Study? A Comparison of the Information Literacy Skills of Commencing Undergraduate and Postgraduate Information Studies Students at Curtin University," Australian Academic \& Research Libraries 42, no. 2 (2011): 121-35, https://doi.org/10.1080/0004 8623.2011.10722218.

8. Association of College and Research Libraries, Framework for Information Literacy for Higher Education (Chicago: American Library Association, 2015), http://www.ala.org/acrl/standards /ilframework

9. Nina Exner, "Research Information Literacy: Addressing Original Researchers' Needs," Journal of Academic Librarianship 40, no. 5 (2014): 463, https://doi.org/10.1016/j.acalib.2014.06.006.
10. Texas A\&M University Data and Research Services, "Enrollment Profile" (Fall 2019), http://dars.tamu.edu/Student/Enrollment -Profile.

11. Texas A\&M University Distance Education, "Distance Degrees," accessed January 29, 2020, https://distance.tamu.edu/Current -Students/Distance-Degrees.

12. Hanna Gascho Rempel, "A Longitudinal Assessment of Graduate Student Research Behavior and the Impact of Attending a Library Literature Review Workshop," College \& Research Libraries 71, no. 6 (2010): 532-47, https://doi.org/10.5860 /crl-79; Hanna Gascho Rempel and Jeanne R. Davidson, "Providing Information Literacy Instruction to Graduate Students through Literature Review Workshops," Issues in Science and Technology Librarianship 53 (2008): 1-17, https://doi.org/10.5062 /F44X55RG.

13. Sharon Ince, Christopher Hoadley, and Paul A. Kirschner, "The Role of Libraries in Teaching Doctoral Students to Become Information-Literate Researchers: A Review of Existing Practices and Recommendations for the Future," Information and Learning Sciences 120, no. 3/4 (2019): 167, https://doi.org/10.1108/ils-07 -2018-0058.

14. Kathy Anders, Anna Dabrowski, and Cecilia Smith, "Small Steps to Giant Leaps: Strategies for Creating Effective Graduate Information Literacy Programming" (Conference presentation, LOEX Annual Conference, Houston, May 5, 2018), accessed January 29, 2020, http://hdl.handle.net/1969.1/166396.

15. Ronan Madden, "Information Behavior of Humanities PhDs on an Information Literacy Course," Reference Services Review, 42, no. 1 (2014): 90-107, https://doi.org/10.1108 /rsr-07-2013-0034; Jane Secker and Rowena Macrae-Gibson, "Evaluating MI512: An Information Literacy Course for PhD Students," Library Review 60, no. 2 (2011): 96-107, https://doi .org/10.1108/00242531111113050.

16. Texas A\&M University, "Instruction Stats Summary" (January 1 , 2019-December 31, 2019), accessed January 29, 2020.

17. Hilary Bussell, Jessica Hagman, and Christopher S. Guder, "Research Needs and Learning Format Preferences of Graduate Students at a Large Public University: An Exploratory Study," College \& Research Libraries 78, no. 7 (2017): 991, https://doi .org/10.5860/crl.78.7.978.

18. Maria Grant, and Marlowe Berg, "Information Literacy Integration in a Doctoral Program," Behavioral \& Social Sciences Librarian 22, no. 1 (2003): 115-28, https://doi.org/10.1300/J103 v22n01_08.

19. Rebecca K. Grady et al., "Betwixt and Between: The Social Position and Stress Experiences of Graduate Students," Teaching Sociology 42, no. 1 (2014): 11, https://doi.org/10.1177/0092055X13502182.

20. Lori Critz et al., "Development of the Graduate Library User Education Series," Reference Services Review 40, no. 4 (2012): 530-42, https://doi.org/10.1108/00907321211277341; Bettina Peacemaker and Martha Roseberry, "Creating a Sustainable Graduate Student Workshop Series," Reference Services Review 45, no. 4 (2017): 562-74, https://doi.org/10.1108/rsr-04-2017 -0010 . 